Review

\title{
Review on Apiary Management and Antimicrobial Compounds as Alternative Prevention or Treatment for Honeybee Diseases
}

\author{
${ }^{1}$ Chanpen Chanchao, ${ }^{2}$ Marko Stoić, ${ }^{2}$ Mikio Yoshiyama and ${ }^{2}$ Kiyoshi Kimura \\ ${ }^{1}$ Department of Biology, Faculty of Science, Chulalongkorn University, 254 Phayathai Road, Bangkok 10330, Thailand \\ ${ }^{2}$ Honeybee Research Group, National Institute of Livestock and Grassland Science, Ibaraki 305-0901, Japan
}

\author{
Article history \\ Received: $28-08-2017$ \\ Revised: $18-10-2017$ \\ Accepted: 11-01-2018 \\ Corresponding Author: \\ Chanpen Chanchao \\ Department of Biology, Faculty \\ of Science, Chulalongkorn \\ University, 254 Phayathai Road, \\ Bangkok 10330, Thailand \\ Tel: +662-218- 5380 \\ Fax: +662-218-5386 \\ E-mail: chanpen.c@chula.ac.th
}

\begin{abstract}
Honeybees are important in terms of pollinators and bee products. However, honeybee colonies keep declining due to colony collapse disorder, loss of food sources, environmental deterioration, pesticide exposure and various diseases, as well as the interaction of these causes. Pathogenic infections are high because there is an antagonistic coevolution between host and pathogen/parasite, which leads to a reciprocal adaptation, as well as the weakening of the immune system of the hosts by other (including the above mentioned) compounding factors. Since many antibiotics have been used in apiaries, there is growing public health concern about antibiotic residues in food, while the spread of antibiotic resistant isolates of pathogens is of concern. This review focusses on a management system for apiary hygiene and antimicrobial compounds from natural products. Important traits for apiary management are the habitat quality, landscape heterogeneity, climate, management and health. Successful management can be determined by many criteria, such as the level of honey production/harvesting, the diversity of honey types, disease control and pesticide accumulation. Furthermore, attention to land cover is important because it provides the quality and quantity of nutrients. High elevations and slopes can influence the bee health, as can human actions, including global trade and hobby bee keepers. In order to reduce the use of chemicals and antibiotics in apiaries, the use of alternative compounds from natural products are still required. Compounds inhibiting Paenibacillus larvae larvae, the cause of American foulbrood disease and Varroa mites are very challenging because the bacteria can produce resistant spores and the mites are vectors for many viruses and pathogens. Bee products and plants, both crude and purified forms, can be alternative sources for honeybee disease control. Several substances, like propolis, have already been applied in field experiments. Various crude extracts, volatile compounds and pure compounds appear to have potential in honeybee disease prevention and treatment. It is concluded that the apiary management system and use of suitable alternative compounds from natural products can improve the health and decrease the loss of honeybees.
\end{abstract}

Keywords: Alternative Compound, Bee Disease, Colony Loss, Honeybee, Management System

\section{Introduction}

Honeybees are ecologically and economically important since they are pollinators and their products are very useful. The commercial pollination industry in the US provided nearly $\$ 20$ billion in crop value (Gallai et al., 2009). Among insect pollinators, Apis mellifera contributes the most to agriculture and has been 
estimated to be more than $\$ 14$ billion annually (NAS, 2007). In 2015, honeybees in Canada alone produced more than 95.3 million pounds of honey with a total retail value of \$ 232 million CND (Nagamuthu, 2016).

However, the number of bee colonies has declined dramatically recently. For example, US bee keepers have lost approximately $30 \%$ of their colonies each winter (vanEngelsdorp et al., 2012). This might be due to the loss of flower-rich habitats, nesting sites, monotonous diets, impacts of invasive pathogens and parasites, pollution, weather, management, habitat loss and fragmentation, environmental deterioration and exposure to pesticides (Dance et al., 2017; Schick et al., 2017). The concern of bee health was first reported by Oldroyd (2007) in terms of Colony Collapse Disorder (CCD), a phenomenon where honeybee workers abandon their colonies despite an abundance of brood and food store. Honeybees, like other social insects, live in high densities within a hive. Thus, contaminating or infecting pathogens can spread quickly and widely owing to the ease of transmission among nest mates (Schmid-Hempel, 1998). Also, pathogens and parasites can spread to many areas because managed (domesticated) bee colonies are transported widely by man within and between agricultural areas. Honeybees perform hygienic hive behavior, a heritable social immunity response that confers disease resistance to the colony by eliminating brood pathogens from the hive (Spivak and Reuter, 2001) and grooming behavior, which consists of self-cleaning, grooming dance, nestmate cleaning and group cleaning (Zhukovskaya et al., 2013). However, they are still contaminated or infected with pathogens and parasites. In contrast, Bigio et al. (2014) reported that they did not support the cost-to-healthy-brood hypothesis since Apis mellifera removed $2-44.4 \%$ untreated broods as well as $19.7-100 \%$ introduced freeze-killed broods using hygienic behavior.

The pathogens and parasites causing honeybee diseases are bacteria (American foulbrood by Paenibacillus larvae and European foulbrood by Melissococcus plutonius), fungi (chalkbrood by Ascosphaera apis), microsporidia (Nosemaapis and N. ceranae) and viruses. Furthermore, mites (Varroa destructor) as ectoparasites can cause devastating losses of honeybees through direct feeding, vectors for transmitting diseases and increasing pathogen and parasite susceptibility. In addition, it was reported that there is interaction between viral pathogens and Varroa mites, where a high frequency of Deformed Wing Virus (DWV) and Chronic Bee Paralysis Virus (CBPV) is correlated with high mite infestation levels (Rinkevich et al., 2017).

Although there are more than 20,000 species of bees (Hymenoptera: Apoidea: Anthophila), it is obvious that bees in the genera of Apis and Bombus are the most well studied in any aspects of research (Ascher and Pickering,
2015). Also, among Apis spp., A. mellifera is the most well studied due to its role in global cultivated honey production. As such, A. mellifera is the most common managed pollinator and can be responsible for $90 \%$ of active agricultural pollination from its commercial apiaries (Graystock et al., 2016).

Host and pathogen/parasite have an antagonistic coevolution resulting in reciprocal adaptation. In general, an infection or disease can lead to a severe reduction in host survival and reproductive success. Although hosts have an immune function, immunocompetence is a costly process (Schmid-Hempel, 2005). Thus, natural selection prefers tolerant hosts that can sustain a pathogen/parasite infection to a resistant host (Sorci, 2013). In contrast, a well-adapted pathogen/parasite will escape or reduce the potential of host's immune system (Schmid-Hempel, 2008). Microsporidia, which includes $N$. ceranae and $N$. apis, are intracellular fungi that lack mitochondria and so are dependent on the host's energy metabolism, can infect many host species (Keeling, 2009). For example, N. ceranae, originally described in Apiscerana, can cross-infect A. mellifera. This host and pathogen/parasite coevolution could select for genetic variation for both pathogen/parasite virulence and host resistance, but data on the health of wild honeybees and other pollinators are scarce (Potts et al., 2010).

Recently, the development of the "-omictechnologies" has allowed a lot of data to be obtained within a short time, such as in genomics (by next generation sequencing), transcriptomics (by RNA sequencing, expressed sequence tag library) and proteomics (by twoDimensional Sodium Dodecyl Sulphate-Polyacrylamide Gel Electrophoresis (2D-SDS-PAGE) and liquid chromatography tandem mass spectrometry; LC-MS/MS). To reveal the complexity of honeybees, dynamic gene expression by transcriptomics and proteomics is required after the genomics data have been revealed.

Genome sequences are useful in many aspects. For example, they can be applied for developing new pest control methods, identifying candidate antigens to vaccinate livestock and discovering RNA interference (RNAi) target sequences and potential non-target effects in many insects. Gene content analyses of genome sequences may suggest metabolic interdependencies between organisms and the evolution and complex relationship between pathogen/parasite relationships (Poelchau et al., 2016). This information may then result in identifying potential gene targets for pathogen/parasite control and provide new insights into the molecular mechanisms underlying their pathogenicity/host resistance. With the advances in next generation sequencing technology, the complete genome of $A$. mellifera has already been completed while that for other related species, including $A$. dorsata and $A$. florea, are in the progress (HGSC, 
2014; Elsik et al., 2016). Interestingly, in addition to the genomes of bees, the genomes of the bee pathogens and parasites of Varroa destructor, Ascosphaera apis, Nosema ceranae and Paenibacillus larvae are also now available through the BeeBase website (http://hymenopteragenome.org/beebase/). Moreover, the genome sequence of Melissococcus plutonius ATCC 35311, which caused European foulbrood, has been completed and deposited in the DNA database of Japan under accession no. AP012200 (for chromosome) and AP012201 (for plasmid). The genome was sequenced using the Roche genome sequence FLX Titanium and consists of a single circular chromosome of 1,891,014 bp with an average GC content of $31.4 \%$, plus a plasmid of 177,718 bp with an average GC content of $29.2 \%$. Within the complete genome, only two genes involved with calcium were annotated, although $M$. plutonius requires potassium to grow (Okumura et al., 2011).

Besides those pathogen/parasites, viruses are also a major cause of bee diseases and their genomes are being revealed continuously. For example, one neglected virus species (A. mellifera Filamentous Virus (AMFV) as the only honeybee virus containing a double stranded DNA genome) and two newly discovered viruses, bee MaculaLike Virus (BeeMLV) and Lake Sinai Virus (LSV), were recently reported. The AMFV genome, obtained by Illumina Hiseq sequencing, has a genome of 498,500 bp (GC content of $50.8 \%$ ) and so it is the largest known honeybee virus genome. Although 13 Open Reading Frames (ORF) were similarly matched to typical baculovirus, many of the ORFs (total of 247 nonoverlapping ORFs) are still unknown. Thus, it may belong to a new virus family. This virus is currently only known from honeybees and has not, for example, been found in varroa mites. From its genomes equence, a PCR-based diagnostic assay has been developed for its detection (Gauthier et al., 2015).

Genome analysis of the Bee MLV revealed that this virus should be placed into the order Tymovirales, family Tymoviridae, genus Maculavirus instead of being a plant virus. It has a polyadenylated RNA genome of about 6,500 bases. The polyadenylation helped in identifying the 3' terminus precisely. Its genome is similar to Bombyxmori macula-like latent virus and Culextymolike virus. This virus can be found both in honeybees and varroa mites, while sub-genomic RNA analyses suggests that honeybees are hosts while varroa mites are possible hosts and likely vectors (De Miranda et al., 2015).

Furthermore, the LSV was found in varroa mites and showed an association with CCD. It had previously been identified to be close to CBPV. However, after considering the sequence variation, host range, prevalence and relation to colony health, it is viewed as being distinct from CBPV, supported by the observation that LSV forms a separate monophyletic clade but related to CBPV (Daughenbaugh et al., 2015).
Environmental nutrients are very important for the growth and survival of any organism and this includes the development of an immune response. In contrast, an improper diet will increase the host's susceptibility to pathogens. Hence, it is important to understand how nutrition influences organisms. Recently, nutrigenomics has been introduced to determine the relationship between health and nutrition by integrating highthroughput genomics tools with nutrition research (Muller and Kersten, 2003). For the honeybee, pollen provides most of the nutrients. Not only does the proper quantity and quality of pollen reduce the bee's sensitivity to pesticides, but it helps honeybees to be more tolerant to bee diseases by increasing the honeybee's immune function (Alaux et al., 2010). The influence of pollen nutrients on the transcriptomic change of bees with or without a pollen dietand with or without being parasitized by varroa was examined using the whole abdomen of workers (Alaux et al., 2010), because it contained the midgut, where the pollen is digested, nutrient storage and fat body, which is the main site for antimicrobial peptide synthesis, immune defense and pesticide detoxification. By using Digital Gene Expression (DGE) analysis, it was revealed that pollen activates nutrient-sensing and metabolic pathways. Since pollen increased the level of vitellogenin that was synthesized in the fat body and had antioxidant function, it indicated that pollen had a positive effect on longevity. Considering the expression level of Prophenoloxidase (PPO), which is involved in insect immunity, pollen feeding did not increase the PPO level even though varroa parasitism inhibited PPO expression. Thus, the level of pollen intake is not able to reverse the inhibited metabolism, including protein metabolism inhibition, after varroa parasitism. In contrast, since fluvalinate and coumaphos are abundant in bee hives in the US., Schmehl et al. (2014) used workers treated with $0.1 \%$ (w/v) sucrose daily with either long-term (fed throughout) or short-term (fed $24 \mathrm{~h}$ before initial pesticide exposure) pollen or soy protein feed, compared to those fed with only $0.1 \%(\mathrm{w} / \mathrm{v})$ sucrose. On day- 5 , bees in each group were divided into two subgroups. The first four subgroups were fed with $0.1 \%(\mathrm{w} / \mathrm{v})$ sucrose solution containing $3 \mathrm{ppm}$ chlopyrifos while the latter four subgroups were fed with $0.1 \%(\mathrm{w} / \mathrm{v})$ sucrose. After 16 days, the survival rate of honeybees in each group were determined. It was obvious that the pollen-based diets reduced the worker's pesticide sensitivity, especially to chlorpyrifos. Additionally, the expression levels of many pesticide detoxification genes were upregulated in response to pollen feeding.

Transcripts from bee larvae inoculated with $P$. larvae (100 spores $/ \mu \mathrm{L}$ food) at $12 \mathrm{~h}$ post-emergence and then incubated at $34^{\circ} \mathrm{C}$ and high humidity for $72 \mathrm{~h}$ were sequenced by Illumina sequencing. Seven genes encoding antimicrobial peptides were found to be upregulated, along with two genes encoding peritrophic- 
matrix domains (Cornman et al., 2013). This is reasonable because the peritrophic matrix is the first line of defense against germinating bacterial spores. Moreover, it forms a physical barrier, comprised of chitin and protein, surrounding the ingested material in the midgut lumen. This barrier has to be breached prior to systemic infection (Yue et al., 2008). However, the amount and type of antimicrobial proteins varies genetically, while there may be variation in the protein components of the peritrophic protein (Evans et al., 2006). Comparing the transcript expression level at 48 and $72 \mathrm{~h}$ post infection (pi), it was obvious that apidaecin was responsive at both time-points. Although hymenoptaecin showed the greatest increase in expression, its expression level was more consistent in between two time-points (Cornman et al., 2013).

$\mathrm{Wu}$ et al. (2017) suggested that it is important to understand the synergistic effects of parasitism on honeybee colonies. Understanding the resistance mechanisms of the honeybees against pathogens and parasites will help in breeding hybrids, pathogen- and parasite-resistant bees and the development of rationally designed pathogen and parasite prevention methods. Metabolomics, a comprehensive quantitative and qualitative analysis of all metabolites in samples, can be used to evaluate the metabolic processes under given physiological and pathological conditions (Nicholson and Lindon, 2008). Wu et al. (2017) studied the metabolomic profile of brains of healthy and $V$. destructor infested $A$. cerana using untargeted LC-MS/MS. After multivariate statistical analyses, 64 days regulated metabolites, including fatty acids, amino acids, carboxylic acid and phospholipids were identified. Pathway analysis then revealed that the linoleic acid, propanoate, glycine, serine and threonine metabolism were acutely perturbed.

Apis cerana cerana is a native Chinese bee species that is economically importantin the Chinese apicultural industry. It can be infected by Chinese sacbrood virus (CSBV), a small single positive-strand RNA virus that does not infect $A$. mellifera. Since fresh royal jelly of $A$. ceranacerana and $A$. mellifera are quantitatively different in nucleic acids and protein composition (Fang et al., 2010), the role of heterospecific royal jelly was evaluated. Second instar larvae of $A$. ceranacerana were fed with eitherroyal jelly at $80 \%$ relative humidity and $32-34^{\circ} \mathrm{C}$ for $24 \mathrm{~h}$. After $24 \mathrm{~h}$, when the second instar larvae had become third in star larvae, the most sensitive stage to CSBV infection, they were challenged with 30 $\mu \mathrm{L}$ of CSBV solution $\left(7.9 \times 10^{5}\right.$ copies $\left./ \mathrm{mL}\right)$ per cell. Feeding with heterospecific royal jelly had no significant effect on the bee mortality, but $A$. ceranacerana larvae fed with $A$. mellifera royal jelly and subsequently challenged with CSBV had a significantly lower mortality rate $(27.8 \%)$ than $A$. ceranacerana larvae fed with $A$. ceranacerana royal jelly and subsequently challenged with CSBV (72.2\%). Proteomic analysis, based upon 2D-SDS-PAGEand MALDI-TOF/TOF MS, of the A. ceranacerana larvae fed with A. mellifera royal jelly and subsequently challenged with CSBV, revealed that genes in energy metabolism (majority), antioxidationand ubiquitin-proteasome system were activated (Zhang et al., 2014). However, the role of these gene products in the anti-CSBV activity is unknown.

Miticide, like phenothrin, amitraz and clothianidin, has long been used to reduce mite infestation (Rinkevich et al., 2017). However, the use of such chemicals to control pathogens and parasitesis of concern because agro-chemical contaminants affect the beekeeping development and bee products directly. For example, Amulen et al. (2017) reported that beeswax was mostly contaminated with many fungicides and insecticides, such as neonicotinoid (acetamiprid, $0.012 \pm 0.021 \mu \mathrm{g} / \mathrm{kg}$ ), organophosphates (chlorpyrifos, $0.052 \pm 0.028 \mu \mathrm{g} / \mathrm{kg}$ ), carbamate (carbendazim, $0.006 \pm 0.003 \mu \mathrm{g} / \mathrm{kg}$ ) and dimethyldithiocarbamate (thiram, $0.102 \pm 0.114 \mu \mathrm{g} / \mathrm{kg}$ ), as detected by LC-MS/MS and Gas Liquid Chromatography with Electron Capture (GLC-ECD). Although these agrochemical levels were still lower than the lethal threshold, future risk assessment is needed. Chronic exposure to low doses leads to sublethal effects in individual bees and, eventually, will result in colony-level effects (Johnson et al., 2010). In addition, this is a serious obstacle to the promotion of organic bee products, where, for example, residues from over 120 different pesticides have found in honeybee hives in Uganda. Fluvalinate $\left(224 \mathrm{ppm}\right.$ in $2010, \mathrm{LD}_{50}=15.86$ ppm) and coumaphos (94 ppm in 2010 and $514 \mathrm{ppm}$ in $2013, \mathrm{LD}_{50}=46.3 \mathrm{ppm}$ ) were the two most abundant (about 98\%) pesticides found to be contaminated in beeswax (Mullin et al., 2010; Berry et al., 2013). In addition, contaminating pesticide residues can affect gene expression in honeybees. Schmehl et al. (2014) fed honeybees with $0.1 \%(\mathrm{w} / \mathrm{v})$ sucrose and on the second day, bees in four groups were fed with $0.1 \%(\mathrm{w} / \mathrm{v})$ sucrose solution alone or supplemented with $3 \%(\mathrm{v} / \mathrm{v})$ methanol (solvent control), $100 \mathrm{ppm}$ fluvalinate dissolved in methanol or $100 \mathrm{ppm}$ coumaphos dissolved in methanol, respectively. After $7 \mathrm{~d}$ the genome-wide gene expression pattern of the bees was examined, where 814 out of 1,118 transcripts were significantly differentially expressed among the coumaphos and/or fluvalinate and the sucrose groups. Several genes involved in detoxification had significantly altered expression levels in response to the pesticide exposure.

Many factors have been reported to affect immune and pesticide response genes. However, CCD, a mysterious phenomenon in which the colony rapidly declines, was shown not to directly involve those factors. Honeybee gut transcriptome analysis of CCD originating from the east and west coast of the US and non-CCD colonies, analyzed by whole-genome microarray, had largely unchanged expression levels of immune and pesticide response genes. Also, although the east and 
west coast differ in their geography, there was no difference in the expression of CCD-related genes. However, DWV and rRNA-like transcripts that were found to abundant in CCD colonies could be used for the earlier diagnosis of CCD status (Johnson et al., 2009).

For decades, antibiotics have been used for the treatment of bee diseases. For example, oxytetracycline, streptomycin, sulphathiazole and chloramphenicol have been used to treat pathogenic bacteria (Gacic et al., 2015). However, excess amount of these antibiotics can contaminate the bee products, where antibiotic residues in food are of increasing public health concern. Many methods have been developed to detect antibiotic residues more efficiently, such as dispersive micro solid-phase extraction approach coupled with liquid chromatographyhigh-resolution mass spectrometry (Hu et al., 2017). In addition, extensive resistance to Oxytetracycline (OTC or Terramycin $\left({ }^{\circledR}\right)$ in $P$. larvae in the us has been found using antibiotic susceptibility testing (disk diffusion method), where OTC, tetracycline, tylosin and lincomycin-resistant isolates were found at 15.78, 21.05, 7.8 and $7.8 \%$, respectively (Krongdang et al., 2017). Furthermore, long term exposure of antibiotics to honeybees can adversely affect the gut microbiota by impacting upon non-target microbes. This can cause the accumulation of resistance determinants, which are encoded on mobile genetic elements that are readily transferred among different community members. The main concern here is that those gut communities may act as reservoirs for resistance genes that can be transferred to pathogens (Marshall et al., 2009). Antibiotic production and resistance mechanisms are widespread in natural microbial communities (Davies and Davies, 2010). A functional metagenomic screen of gut bacteria from honeybees from diverse localities in the US subjected to antibiotic treatment for decades revealed eight tetracycline resistance loci (Tian et al., 2012).

Thus, an alternative method to prevent and treat these bee pathogens and parasites is required to maintain colony health, given the importance to commercial pollination and the bee product industry.

\section{Management System for Hygiene Apiary}

The global decline in bee populations can be caused by many factors, both inside and outside of the colony. In managed apiaries, pathogens/parasites can be dispersed from hive to hive by honeybee behavior, such as reduced swarming and foragers robbing or drifting between hives (DeGrandi-Hoffman et al., 2017). It is mainly involved with environmental factors and health status. Factors that lead to stress in honeybees, such as pesticide, transport, honey extraction, loss of honey reserves in the hive, wax re-use, nutrient deficiency (such as pollination in monocultures or other areas of low plant species richness and shortening of the flowering period), presence of nearby apiaries, overcrowding in the apiary, land-use change that decreases nutritional resources and climate change (Asensio et al., 2016). A summary of honeybee decline was given by Asensio et al. (2016), who stated it is related to the five criteria of habitat quality, landscape heterogeneity, climate, management and health. Analyzing six apiaries in different Mediterranean environments in Spain with a multi-criteria decision analysis (analytical hierarchy process), the habitat quality was indicated as the most important of the five criteria. Interesting data included that with respect to the habitat quality, the most preferable habitat for honeybees contained $>$ ten land cover types, $>12$ important vegetable species in each area, an absence of major roads and industrial estates, large water reservoirs $(\leq 50 \mathrm{~m})$ or urban areas, slope ranges from $5^{\circ}$ to $10^{\circ}$ and a high elevation range of 540 $\mathrm{m}$ above mean sea level (amsl). With respect to beehive management, excellent conditions were defined by a honey production level of 15-70 kg/colony, many honey types, Varroa treatment by ethereal oil or organic acids, reduced pesticide treatment, treatment risk by bee toxicity data, product degradation and accumulation in beeswax, frequent wax renewal, light color wax with adequate origin, apiary movement for nutrition and no extensive livestock nearby. Although the selected apiaries in that study were in good status, a larger number of apiaries and study years are still required to develop a spatiotemporal model and confirm the decision model.

The importance of land cover was supported by Clermont et al. (2015), where the land cover types by crops, which differ in the quality and quantity of nutrients, were always changed due to crop rotation, while other positions, like rivers, road, forests and so on, remained unchanged in each year. Again, to support this correlation between land cover type and honeybee loss, more data are needed to be recorded for many years. Data of colony losses per apiary and colony death in Luxembourg in 2010-2012 (Clermont et al., 2014) combined with agricultural land use data from the same period (Ministry of Agriculture), where the crop data were from farmers receiving subsidy payments, were analyzed. A total of 67 agricultural land use types and 66 land cover types (not agricultural related) within a radius of $5 \mathrm{~km}$ around apiaries were used for the analysis because the longest distance for foraging honeybees was up to $5.983 \mathrm{~km}$ (Hagler et al., 2011). In addition, the average distance for foraging was $2 \mathrm{~km}$ (Clermont et al., 2015). Thus, the study evaluated land use and colony losses within a radius of 2 and $5 \mathrm{~km}$ around the apiaries. Honeybee losses increased repeatedly in many areas occupied by transport, industry, leisure, artificial surface water and dense settlements, while honeybee losses decreased repeatedly in areas occupied by cultivated grain maize, peas, legumes and spelt. However, the role of forests is still equivocal. It could be hypothesized that 
the declining number of honeybee colonies depended on the expansion of developed land. Crops with a developmental time lag before flowering of 3-5 y and areas with forest clearings had a negative impact on the colony survival, while old open cast mines or the land use following open cast mining had a positive impact on the colony survival.

The influence of high elevation and slope on bee health was supported by Chemurot et al. (2016). They compared two agro-ecological zones (eastern and western highlands) in Uganda that were about $546 \mathrm{~km}$ apart from each other within an altitude range from 930-2,400 m amsl. The apiaries were selected based on altitudinal gradients and land uses and were divided into the four strata of low (900-1,100 mamsl), mid-low (1,101-1,300 mamsl), high (1,301-1,500 mamsl) and very high (above 1,500 mamsl) altitude. Apiaries were at least $3.5 \mathrm{~km}$ apart from each other to avoid cross foraging. Mite infestation level was obtained from the number of mites per worker bee. For the 2-y sampling period, the mite prevalence rate between the two zones did not depend on the seasons but varied significantly along the altitudinal gradient only in the dry season. In addition, in the dry season, the mite infestation level was significantly different in the two zones and was negatively correlated with the altitude and significantly depended on the apiary slopes. The infestation level was significantly lower in steep slopes compared to flat and gentle slopes. In contrast, locations with different habitat categories, the distance to the nearest water source, beehive height from the ground and beehive types (traditional, Johnson's, Kenyan top-bar, Tanzanian top-bar and Langstroth beehive types) had no apparent influence on the mite infestation level. Moreover, the mite infestation level was not correlated to the honey productivity and the strength of the colonies. Since Varroa was a new ecto-parasite in Uganda, these data will be good for mite management in the country.

Owen (2017) stated that human action is the main problem that helps spread the pathogens/parasites. Global trade in honeybee and its products can spread pathogens/parasites, while migratory beekeeping, especially for modern intensive agriculture, can spread pathogens within the country (Multinelli, 2011; Crane, 2000). International trade in honeybees and bee products are obvious potential carriers of non-native pathogen/parasite species. Varroa destructor, regarded as the most global threat to honeybees, is an example. Originally, Varroa was found in north-east Asia associated with its natural host, A. cerana, the native Asian honeybee. Later, it successfully infested $A$. mellifera, European honeybees, after Eastern Russia imported A. mellifera to that region in 1905 (Oldroyd, 1999). After a large-scale movement of $A$. mellifera, especially through illegal importation of queens or honeybees, hitchhikers, or swarm in containers or vessels, Varroa mites have spread worldwide and included the spread of an exotic pathogen at a shipping port or an airport, too. Thus, restricted quarantine should be practiced. Gordon et al. (2014) reported that migratory beekeeping cultures are common in the US and Australia. Thus, pathogens/parasites can easily be dispersed throughout the country.

Beekeepers' management strategies and hobby beekeepers play a crucial role in the decline of honeybees as well (Traynor et al., 2016). In order to control the pathogens/parasites efficiently, some beekeepers have only considered how fast pathogens/parasites can be reduced or killed and so used an overdose of pesticides or used unapproved pesticides, resulting in the hive becoming contaminated with these chemical residues, especially the beeswax and leading eventually to resistant pathogens/parasites. Hobby beekeepers often do not have sufficient skills, time or interests to manage and maintain the colonies in a good condition all the time, so they can face the difficulty of managing diseased colonies. In contrast, Winfree et al. (2009) presented a meta-analysis review of the published literature, which revealed that managed honeybee abundance and species richness was not significantly associated with human disturbance but they were only significantly reduced by habitat loss in systems experiencing extreme habitat loss.

For better management, it is essential to identify the pathogen/parasite haplotypes or genotypes since they may differ in virulence. For example, P. larvae can be classified into four genotypes using the Enterobacterial Repetitive Intergenic Consensus (ERIC I-IV) sequence. ERIC I and II are globally spread but ERIC III and IV are localized. All four genotypes differ in many aspects, including their virulence (Genersch et al., 2006). Recently, Multilocus Sequence Typing (MLST) was successfully used to genotype Japanese $P$. larvae, revealing three genotypes of ERIC I-ST2, ERIC I-ST15 and ERIC II-ST10. ERIC I-ST2 was found to be outside the native range of $A$. mellifera due to importation since the year of 1877 (Hirai et al., 2016). ERIC I was reported to be less virulent than ERIC II (Genersch et al., 2005) and so this data was important for the control and treatment of $P$. larvae.

Krongdang et al. (2017) used MLST to investigate the genetic diversity of 33 isolates of $P$. larvae collected from different locations in the US. Considering the sequence polymorphism of seven housekeeping genes, they had a low level of nucleotide and haplotype diversity. Although, ERIC- and Box PCR analyses placed all the isolates in the ERIC I genotype, they were different in their susceptibility towards antibiotics (OTC, tetracycline, tylosin and lincomycin), where resistant and susceptible isolates were clearly split. 
Mitochondrial haplotypes have been reported in the $V$. destructor mite with Korean (K) and Japanese haplotypes. The $\mathrm{K}$ haplotype is present worldwide while the $\mathrm{J}$ haplotype is only present in Japan, Thailand, Taiwan and the Americas (Solignac et al., 2005). It was reported that the $\mathrm{K}$ haplotype is much more virulent on $A$. mellifera than the J haplotype (Delfinado-Baker, 1988).

Integrated pest management should be encouraged for pest control in apiary management. In brief, pest control techniques should be considered carefully so as to use appropriate measures that reduce the pest population and minimize the pesticide level to be economically justified and reduce or minimize the risks to human health and the environment (Williams, 2010).

Other than pathogens and parasites, the greater wax moth (Galleria mellonella) is a commonly found pest for honeybees. It causes economic damage because its larvae feed on bee food, cast-off honeybee pupal skin and brood. Also, the wax moth larvae can create silk-lined tunnels through the honeybee cell, which leads to the loss and absconding of the honeybees. For management of the greater wax moth in apiaries, Kwadha et al. (2017) summarized that sanitation, including keeping the colony strong, providing adequate food sources, sealing cracks and crevices, minimizing pesticide application, replacing combs regularly, destroying infested combs showing signs of galleries and providing a proper storage system for hive products, is the most effective management for the greater wax moth.

For American Foulbrood (AFB), burning of diseased colonies and contaminated materials is known to be the most appropriate control (Genersch, 2010). However, that causes a dramatical economic loss for beekeepers. An alternative and effective management technique for AFB is the shaking method, which is a non-antibiotic method. Honeybees are transferred to an uncontaminated comb and the infected comb is then destroyed (Pernal et al., 2008). The contaminated honey in the stomach of transferred honeybees is consumed during the building of new combs. If the colony has a poor tolerance against AFB, a new queen from a tolerant strain should be introduced. Although this method is effective, it is labor-intensive. In England and Wales, AFB control and monitoring is under the control of a government-funded apiary inspection program and operated by the National Bee Unit (www.nationalbeeunit.com) since 1942. Mill et al. (2014) used the data from 1994-2012 from this program to examine the pattern and spread of AFB in order to understand its epidemiology. The results indicated that the majority of clusters did not persist in all years and occurred at a peak of 10-20 km, strongly supporting the local between-apiary spread of AFB, facilitated by honeybees and beekeeping behavior. Thus, management measures may lead to localized extinction of disease.

Global knowledge for honeybees and pest and pathogen research is important for the bee industry. Thus, the prevention of honeybee colony losses
(COLOSS) honeybee research association has published bee books relating to standard methods for bee research (www.coloss.org/beebook).

\section{Antimicrobial Compounds}

As already mentioned, the chemicals and antibiotics used to treat bee diseases are problematic and costly. Thus, the search for alternative, especially nontoxic, natural compounds with a high antimicrobial activity and low toxic effects to control bee diseases is needed. Most research has focused on P. larvae and varroa mites. Paenibacillus larvae is hard to eradicate due to its ability to produce spores. Since varroa are vectors for bee infecting viruses and pathogens, controlling varroa can indirectly control viral and other pathogen bee diseases. Interestingly, although honeybees are infected by P. larvae and infested by varroa, bee products are reported to contain many compounds with anti- $P$. larvae and anti-parasitic activities. Both activities can be found in the crude extract, partially purified and purified active compounds. Crude extracts are good in terms that local people can access it easily, since the raw materials are mostly local, it is cheap and easy to perform without the need for sophisticated equipment. In addition, the activity from synergistic compounds is preserved. Since minor or less side effects are found from crude extracts, they fall into organic treatment. Pure compounds are good in terms of allowing for standardized activities and known composition (quality control) and they reveal the chemical structure of the active compounds, but are expensive and omit unknown synergistic interactions. Also, some inert compounds are removed. Overall, it is obvious that plants and plant derivatives are important sources for alternative compounds, since plants contain a lot of secondary metabolites. Although those metabolites are not necessary in the basic plant life cycle they are very useful in plant defense mechanisms.

\section{Crude Extracts of Calendula Officinal is, Cariniana domestica and Nasturtium Officinale Plants}

Piana et al. (2015) extracted the flowers of $C$. officinalis, leaves of $C$. domestica and leaves and branches of $N$. officinale from Brazil with $70 \%(\mathrm{v} / \mathrm{v})$ $\mathrm{EtOH}$ to give crude EtOH extracts. The Minimum Inhibitory Concentration (MIC) of the extracts was determined against $P$. larvae (ATCC 9545) by the broth microdilution procedure and 2,3,5-triphenyltetrazolium chloride. Crude EtOH extracts of $C$. officinalis and $N$. officinale exhibited an anti- $P$. larvae activity with a MIC of 12.76 and $30.51 \mathrm{mg} / \mathrm{mL}$, respectively. Since the crude $\mathrm{EtOH}$ extract of $C$. domestica was inactive, it was further partitioned, where the ethyl acetate and n-butanol fractions were found to be active against $P$. larvae with a MIC of 4.06 and $0.98 \mathrm{mg} / \mathrm{mL}$, respectively. It is, of course, important to test the toxicity of any such active samples to honeybees also. Samples were dissolved in DMSO to the 
MIC concentration and 15 honeybees were exposed to them in a petri dish lined with absorbent filter paper and a mesh lid. One $\mathrm{mL}$ of the sample was sprayed onto the honeybees and their mortality was observed daily for $15 \mathrm{~d}$. The crude EtOH extract of $C$. offininalis was the least toxic to honeybees, where after $4 \mathrm{~d}$, the surviving number of exposed honeybees was almost constant at $70 \%$.

\section{Crude Ethanol Extract of Laurel Leaf}

Damiani et al. (2014) collected Laurus nobilis leaves in Buenos Aires, Argentina. The dried leaves were steam distilled to provide the Essential Oil (EO) and the hydrolate (the aqueous solution by-product of the distillation that contains many hydrophilic compounds). In addition, pure 1,8-cineol, the main compound in hydrolate and EO, was used. The dried leaves were also extracted with $80 \%(\mathrm{v} / \mathrm{v}) \mathrm{EtOH}$ to yield the crude EtOH Extract (EE). Then, the anti-P.larvae activity, as the MIC, was determined for each by the microdilution assay, where the EE was found to be the most active against $P$. larvae (208 $\mu \mathrm{g} / \mathrm{mL}$ for four strains and $416 \mu \mathrm{g} / \mathrm{mL}$ for one strain).

The anti-parasitic activity was also evaluated using topical application. The EO and hydrolate were prepared at various doses by diluting with $96 \%$ (v/v) EtOH, while the EE was dissolved in a solution of $20 \%(\mathrm{v} / \mathrm{v})$ Dimethyl Sulfoxide (DMSO) in 55\% (v/v) EtOH (to reduce the viscosity) and then the respective test dilution of EO, EE or hydrolate was applied to the bottom of petri dishes, padded with an absorbent filter paper and with a mesh lid. Five female Varroa destructor mites were transferred to each petri dish for various contact times and then removed to a clean petri dish containing six honeybee pupae as food. The result showed that EE was the most effective mitocide at 1 and $24 \mathrm{~h}$ exposure with a $\mathrm{LD}_{50}$ of 3.2 and $2.68 \mu \mathrm{g} / 200 \mu \mathrm{L}$, respectively, while EO was the most effective at 48 and $72 \mathrm{~h}$ of exposure with a $L_{50}$ of 32.66 and $11.69 \mu \mathrm{g} / 200 \mu \mathrm{L}$, respectively.

Microsporicidal activity was ascertained by oral administration. Honeybees (25-30 honeybees per replicate, three replicates) at $3 \mathrm{~d}$ post-emergence were supplied with $60 \%(\mathrm{w} / \mathrm{v})$ sugar syrup solution mixed with different diets (1,8-cineol (positive control), hydrolate, EO or EE) and with different doses of each diet. At the same time, $10 \mu \mathrm{L}$ of the sugar syrup solution containing $2.03 \times 10^{4}$ Nosemas pores were supplied ad libitum. At 7 and $19 \mathrm{dpi}$, the midgut of honeybees was quantified for Nosema spores. The higher concentration of EE caused a higher mortality of infected bees, but EO and 1,8-cineol did not. However, EE inhibited Nosema spore development in the midgut of honeybees. For toxicity to honeybees, both contact and oral toxicity tests were done. Only EO was toxic to honeybees, while the other extracts caused no honeybee mortality. Overall, EE was suggested to be a promising botanical extract to control those three major diseases. It is good that only one sample can control all three major bee diseases at the same time.

\section{Crude Methanol Extracts of Lepidium latifolium} and Zataria multiflora

Razavi et al. (2015) extracted the dried leaves of Lepidium latifolium, perennial pepper weed and Zataria multiflora, one of the most common herbal medicines in Iran, in pure methanol, resulting in crude $\mathrm{MeOH}$ extracts (LlME and ZmME). Thirty hybrid A. mellifera colonies infested with Varroa destructor were used. The LIME and ZmME were prepared in four concentrations (100, 200, 400 and 500 ppm) and apistan, an anti- $V$. destructor agent, was used as the positive control, while distilled water was used as the negative control. Each colony was sprayed with the test solution $(100 \mathrm{~mL})$ at one concentration (total of three colonies). Mites fallen to the technical floor with no movement at 4,8 and $12 \mathrm{~d}$ after treatment were recorded as dead mites. Both crude extracts had a dosedependent (from $\geq 200 \mathrm{ppm}$ ) anti-varroa activity. LIME at $500 \mathrm{ppm}$ was the most efficient and could decrease the mean infestation rate to zero in the treated colonies within $12 \mathrm{~d}$, while it was non-toxic to honeybees, especially compared to the apistan (positive control). Thus, LIME at $500 \mathrm{ppm}$ could be a potential alternative plant-derived product for field application to control varroa.

\section{Crude Ethanol Extract of Baccharis flabellata (BfEE) and Minthostachys verticillata (MvEE)}

Damiani et al. (2011) collected the aerial parts of $B$. flabellataand $M$. verticillatain Argentina and extracted them with EtOH. Various concentrations of the BfEE and $\operatorname{MvEE}(0.5,1,2,4,7$ and $10 \%(\mathrm{w} / \mathrm{v}))$ in $55 \%(\mathrm{v} / \mathrm{v})$ EtOH were applied by spraying as described in Damiani et al. (2014). In brief, five adult female mites and five mite-free adult worker bees were placed into each petri dish. After a mite adhered to the body of a honeybee, $1 \mathrm{~mL}$ of the selected extract and concentration was sprayed onto the honeybee. The number of dead mites and honeybees were counted after 24 and $48 \mathrm{~h}$. Both extracts were toxic to the mites but not the honeybees and their effectiveness was observed early $\left(\mathrm{LD}_{50}\right.$ of $1.57 \%$ for BfEE and $2.16 \%$ for MvEE at $\left.24 \mathrm{~h}\right)$.

For the repellent test, an arena was made from a petri dish divided into two parts. At opposite ends, a circle of paper filter (diameter, $1 \mathrm{~cm}$ ) was placed and $8 \mu \mathrm{L}$ of each $10 \%(\mathrm{v} / \mathrm{v})$ respective EE was placed on the filter, while the other filter was placed with the solvent only $(55 \%(\mathrm{v} / \mathrm{v}) \mathrm{EtOH})$ as the control. After $90 \mathrm{~min}$, the location of mites was recorded. A significant repellent activity was only found for BfEE and so the BfEE could be a potential alternative for mite control.

\section{Volatile Compounds}

Cecotti et al. (2013) analyzed the volatile composition of Trifolium pretense L. ssp. Nivale (snow clover). Aerial parts of $T$. pretense spp. Nivale were collected at three different phonological stages (vegetative stage leaves, 
flowering stage leaves and flowers and fruiting stage leaves and pods) in Italy, in order to evaluate the seasonal variability of the volatile compounds. In the field, samples were stored in dichloromethane $\left(\mathrm{CH}_{2} \mathrm{Cl}_{2}\right)$ to prevent enzymatic modification of the volatile. Compounds were isolated by steam distillation and analyzed by Gas Chromatography (GC) with a Flame Ionization Detector (FID) and GC coupled to Mass Spectrometry (GC/MS). Volatile compounds were identified using their retention indices compared with the coincided data bases. The total amount of volatiles tended to increase with the advancing season. Alcohols were mostly found in all stages, with the linear chain oct-1-en-3-ol being the most abundant and found in the vegetative $(20.8 \pm 2.5 \%)$, flowering $(12.5 \pm 1.2 \%)$ and fruiting $(5.4 \pm 1.1 \%)$ stages, followed by the linear alcohol Z-3-hexenol in the vegetative $(7.4 \pm 0.4 \%)$, flowering $(5.1 \pm 0.7 \%)$ and fruiting $(3.1 \pm 0.5 \%)$ stages and then the branched alcohol 2methyl butanol in the vegetative $(1.7 \pm 0.7 \%)$, flowering $(8.0 \pm 1.0 \%)$ and fruiting $(4.8 \pm 1.1 \%)$ stages. In addition, aromatic alcohols and aldehydes were found only in the flowering stage, perhaps because they are involved in modulating the flower scent (Knudsen et al., 1993). The anti-P. larvae and anti-Melissococcus plutonius activity was ascertained by the agar-well diffusion test, where the $T$. pretense ssp. nivale oil from the vegetative stage was the most active when $2 \mathrm{mg} / \mathrm{mL}$ of sample was used per well. Its activity was a little stronger than the EOs from Cinnamomum zeylanicum leaves. The vegetative phase was mainly composed of the linear alcohols cis-3hexenol, octan-3-ol and oct-1-en-3-ol and so it is possible that one or more of these compounds were synergistically responsible for the antimicrobial activity.

\section{Essential Oils (EOs)}

Essential Oils (EOs) are complex mixtures of low molecular weight volatile constituents biosynthesized by plants. Pellegrini et al. (2017) collected Aloysia polystachia (leaves and flowers), Acantholippia seriphioides (leaves and flowers), Schinus molle (leaves and fruits), Solidago chilensis (leaves and flowers), Lippia turbinate (leaves and flowers), Minthostachys mollis (leaves and flowers), Buddleja globosa (aerial parts) and Baccharis latifolia (aerial parts), native aromatic plants to Argentina, to test for anti- $P$. larvae activity. All fresh materials were hydrodistilled in situ in a steam generator to provide the EOs that were subsequently analyzed by GC/FID to calculate the relative concentration of each compound. Each individual compound was identified by GC/MS from their retention indices compared to those in several databases. The main families of volatile compounds in these EOs were monoterpene hydrocarbons (the highest relative amount in B. latifolia, $69.0 \pm 0.7 \%$ ), oxygenated monoterpenes (the highest relative amount in M. mollis, $90.11 \pm 0.01 \%$ ), sequiterpene hydrocarbons (the highest relative amount in B. latifolia, $12.6 \pm 0.2 \%$ ) and oxygenated sesquiterpenes (the highest relative amount in B. latifolia, $15.4 \pm 0.5 \%$ ). Those EOs were tested for anti-P. larvae by the broth microdilution method, with the criteria that the antimicrobial activity was defined as good, moderate and inactive if the extract displayed a MIC of $<100,500-1,000$ and $>1,000 \mu \mathrm{g} / \mathrm{mL}$, respectively, (Holetz et al., 2002).

All of those EOs displayed a good anti-P. larvae activity, with a MIC range of $12.50 \mu \mathrm{g} / \mathrm{mL}$ for $B$. latifolia to $75 \mu \mathrm{g} / \mathrm{mL}$ for $M$. mollis. Since the individual EOs were very complex and variable in composition, it was difficult to correlate the anti-P. larvae activity with a specific component. Alternatively, it could be implied that the anti- $P$. larvae activity resulted from the interaction of several compounds. It is of concern that the anti- $P$. larvae activity of some compounds could be inhibited by the co-presence of (an) antagonist(s).

To ascertain if EOs could damage the cell membrane of $P$. larvae, the bacteria were treated with EOs at 3 and $4 \mathrm{x}$ the MIC and the alteration of the membrane permeability was detected by the crystal violet assay and the released UV-absorbing material. Crystal violet enters the outer membrane poorly unless it is defective. Also, cell membrane disruption will lead to a leakage of the cell contents, which can be measured in the UV spectrum. All the tested EOs, except B. latifolia, could alter the membrane permeability and make the cells hyper permeable to solute. After the data sets were analyzed by the PLS-R model, many compounds, including carvone, limonene and pentadecane, were found to have a membrane disruption activity on $P$. larvae in a dosedependent manner, but not biciclogermacrene, $\delta$-2-carene, verbenol, $\alpha$-pinene and $\alpha$-thujene.

\section{Cardanol}

A. mellifera propolis, collected from Nan province in the north of Thailand, was extracted with $80 \%(\mathrm{v} / \mathrm{v})$ Methanol $(\mathrm{MeOH})$ to give the crude $\mathrm{MeOH}$ Extract (ME), which had an anti- $P$. larvae activity with an inhibition zone of $1.53 \pm 0.05 \mathrm{~cm}$ in the agar well diffusion assay when $100 \mathrm{mg} / \mathrm{mL}$ of ME was tested. Next, the ME was enriched by quick column chromatography and silica gel 60 gel adsorption chromatography, while the purity of purified fractions were observed by one-dimensional thin layer chromatography. The most active enriched fraction $(20 \mu \mathrm{g})$ could inhibit the growth of $P$. larvae with an inhibition zone of $1.43 \pm 0.06 \mathrm{~cm}$, while streptomycin $(20$ $\mu \mathrm{g}$; positive control) gave an inhibition zone of $2.07 \pm 0.09$ $\mathrm{cm}$. The enriched fraction was determined by nuclear magnetic resonance to be cardanol. However, compared with cardanol, the ME at the same dose gave a larger inhibition zone, suggesting the potential presence of other synergistic compounds. The MIC of cardanol, as determined by the microbroth dilution assay and 2-(4iodophenyl)-3-(4-nitrophenyl)-5-phenyl-2H-tetrazolium 
chloride was reported to be $>50 \mu \mathrm{g} / \mathrm{mL}$. Although the mechanism of action of cardanolis unknown, at 1.75 $\mu \mathrm{g} / \mathrm{mL}$ it caused the formation of smaller cells, especially in dividing $E$. coli cells, that were clumped, damaged and with a high mortality (Boonsai et al., 2014). Cardanol is one of the anacardic acids and is mainly found in natural cashew nuts and mango (Teerasripreecha et al., 2012), consistent with the sampling location of this propolis, where the hives were located in an area full of mango trees. Hence, it was highly possible that honeybees collected mango resin for their propolis production.

Furthermore, this propolis was applied in a field experiment using 10 colonies placed in pairs. Within a row of five colonies (total two rows), each colony was $0.25 \mathrm{~m}$ apart, while each pair of colonies was $1.5 \mathrm{~m}$ apart. Each pair was treated with a high and low amount of propolis separately. In the high-treated colonies, additional propolis was added, obtained from the removal of propolis from the low-treated colonies. Virus and mite infestation, including bee sampling, was performed following the COLOSS guidelines for $A$. mellifera. Although no significant effect of the propolis treatment on mite infestation was found, DWV titers increased less in the colonies that received additional propolis. Also, colonies with added propolis were significantly stronger than colonies with removed propolis (Drescher et al., 2017).

\section{Octanoic Acid}

Knowledge of the chemical communication between the parasite and host could help in developing a new method for parasite control. Mites can infest brood cells from infested nurse bees. Mites differentially infest brood cells containing bee larvae of different sexes and castes, preferring drone (male) cells more than worker cells and they invade queen cells only infrequently. Previously, Calderone et al. (2002) found a miterepellent activity in royal jelly, which only a queen bee eats for her entire life. Nazzi et al. (2009) extracted royal jelly with diethyl ether and analyzed the extract by GCMS. Although many volatile compounds were identified, octanoic acid was the most abundant, with a concentration in the range of $113 \pm 2$ to $252 \pm 8 \mu \mathrm{g} / \mathrm{g}$. For a lab bioassay of mite preference, a glass arena with four wells was used. Two opposite wells contained the treatment while the other two were used as controls ( $1 \mu \mathrm{L}$ of solvent and wait until fully evaporated). One bee larva was placed in each well and an adult female mite was placed in the center of the arena. The position of the mite was recorded every 5 min for $30 \mathrm{~min}$. Compared to the controls and treatments (royal jelly acetone extract, heptanoic acid and nonanoic acid), royal jelly $(10 \mathrm{mg}$ ) and octanoic acid showed the strongest varroa repellency. This may explain why drone and worker cells were more attractive to mites since worker and drone food contained much lower octanoic acid levels at only 3.2-7.6 and 2.1-7.3 $\mu$ g, respectively. For the field assay, $100 \mathrm{ng}$ or $1 \mu \mathrm{g}$ of the respective test compound in $1 \mu \mathrm{L}$ of water was applied to worker brood cells. After $12 \mathrm{~h}$, the sealed cells were opened and inspected to record the number of infested cells. The octanoic acid-treated brood cells were significantly less infested than the control cells and so octanoic acid can be of practical use to control varroa.

Additionally, royal jelly itself has antiMelissococcus plutonius activity. Vezeteu et al. (2017) reported that a royal jelly water extract at any concentration in the range of $2-10 \%(\mathrm{v} / \mathrm{v})$ could prevent the growth of $M$. plutonius $(0.05$ for growth curve slope). The addition of the major royal jelly protein 1 , which was purified from royal jelly, at $500 \mu \mathrm{g} / \mathrm{mL}$ to royal jelly significantly inhibited $M$. plutonius growth (0.00 for growth curve slope, $\mathrm{p}=0.009)$.

\section{Glycerol Monolaurate-Loadedna Nocapsules (GML-NCs)}

Glycerol Monolaurate (GML) is naturally occurring fatty acid (Schlievert et al., 1992). Although it has antimicrobial activity it is poorly soluble in water and has a high melting point, which results in a low bioavailability. Hence, Lopes et al. (2016) tried to encapsulate it according to the method described in Fessi et al. (1989), since the nanoparticles control its release, leading to an increased time of action and a decreased concentration of the active compounds. The GML-loaded Nanocapsules (GML-NCs) had a mean diameter of $209.3 \pm 1.5$, polydispersion index of $0.044 \pm 0.02$, zeta potential of $-23.2 \pm 3$ and a $\mathrm{pH}$ of $6.19 \pm 0.21$. The GML-NCs were tested with $P$. larvae (ATCC9545) as well as three strains of $P$. larvae isolated from different regions (Cobo, Miramar and Chapadmalal) in Argentina. Considering the MIC and Minimal Bactericidal Concentration (MBC), GML had a higher activity than the GML-NCs. The MIC against all four strains of $P$. larvae of 62.2 and $142.8 \mu \mathrm{g} / \mathrm{mL}$ for GML and GML-NCs, respectively, while the MBC for all four strains of $P$. larvae was 142.8 and $285.7 \mu \mathrm{g} / \mathrm{mL}$ for GML and GML-NCs, respectively. In addition, the GML-NCs took a longer time to kill P. larvae in the vegetative/bacillus form, which may result from the controlled release of the compound. However, the GMLNCs had a more efficient sporicidal activity and were less toxic to honeybees than GML.

Overall, it is clear that the use of active compounds from plants as anti-pathogen and anti-parasite agents of honeybees can be performed either as a single enriched component or as a mixture. Additional plants with known anti-pathogen and anti-parasite activities on honeybees are presented in Table 1. 
Table 1: Plants presenting antimicrobial and anti-parasitic activities on honeybees

\begin{tabular}{|c|c|c|c|c|}
\hline Plant species & Location & Active form & Inhibitory against: & Reference \\
\hline Helianthus annuиs L. & Slovak Republic & Freeze-dried bee pollen & P. larvae & Fatrcova-Sramkova et al. (2016) \\
\hline Achyrocline satureioides & Argentina & Hexane extract (Aerial parts) & P. larvae & Gonzalez et al. (2015) \\
\hline Achyrocline satureioides & Argentina & $\begin{array}{l}\text { Hexane extract (Aerial parts) } \\
\text { and surfactin from } \\
\text { Bacillus subtilis } \mathrm{C} 4\end{array}$ & P. larvae & Sabate et al. (2012) \\
\hline $\begin{array}{l}\text { Hypericum canariense, } \\
\text { H. drummondii, } H . \\
\text { mutilum, H. perforatum }\end{array}$ & $\begin{array}{l}\text { North America } \\
\text { and Europe }\end{array}$ & $\begin{array}{l}\mathrm{CH}_{2} \mathrm{Cl}_{2} \text { extract and hyperforin, } \\
\text { uliginosin } \mathrm{B} \text {, uliginosin } \mathrm{A} \text {, } \\
\text { 7-epiclusianone, albaspidin, } \\
\text { drummondin (Flowers and } \\
\text { floral bracts but aerial parts } \\
\text { for } H \text {. perforatum) }\end{array}$ & P. larvae & Hernandez-Lopez et al. (2014) \\
\hline Scutia buxifolia Reissek & Brazil & $\begin{array}{l}\text { Crude dichloromethane } \\
\text { (Stem bark) }\end{array}$ & P. larvae & Boligon et al. (2013) \\
\hline Polygonum bistorta $\mathrm{L}$. & Italy & Essential oil (Aerial part) & $\begin{array}{l}\text { P. larvae, } \\
\text { M. plutonius }\end{array}$ & Cecotti et al. (2012) \\
\hline Azadirachta indica & Mexico & Crude oil extract (Seed) & V. destructor & Gonzalez-Gomez et al. (2012) \\
\hline $\begin{array}{l}\text { Swietenia mahogany, } \\
\text { S. macrophylla }\end{array}$ & Egypt & $\begin{array}{l}\text { Crude ethanol extract (Stem } \\
\text { bark and leaves) }\end{array}$ & V. destructor & El Zalabani et al. (2012) \\
\hline $\begin{array}{l}\text { Thymus vulgaris } \mathrm{L} ., \\
\text { Lavandula officinalis } \\
\text { Chaix ex Villars, } \\
\text { Lavandula hybrid } \text { Rev. } \\
\text { (Lavandula officinalis } \\
\text { Chaix x Lavandula } \\
\text { latifolia Medik) }\end{array}$ & Argentina & Oil (Leaves) & V. destructor & Damiani et al. (2009) \\
\hline Eupatorium buniifolium & & Essential oil (Leaves, twigs) & V. destructor & Umpierrez et al. (2013) \\
\hline $\begin{array}{l}\text { Crataegus pinntifida (Bunge } \\
\text { leaf), Rhododendron } \\
\text { brachycarpum (Fruit), } \\
\text { Polygonum multiflorum } \\
\text { Thunb. (Root), } \\
\text { Cassia brewsteri (Root), } \\
\text { Stephania tetrandra (Root), } \\
\text { Gentiana scabra } \text { Bunge (Root), } \\
\text { Carthamus tinctorius L. (Seed), } \\
\text { Saussurea lappa (Root), } \\
\text { Schisandra chinensis (Fruit) }\end{array}$ & Korea & Macelignan & A. apis & Shin and Kim (2016) \\
\hline Cedar & Egypt & Oil & A. apis & Mourad et al. (2005) \\
\hline
\end{tabular}

\section{Conclusion}

For decades, pesticides and antibiotics have been used to control pathogen/parasites causing honeybee diseases in an apiary, which has resulted in residue contamination in the hive and bee products and the spread of antibiotic/pesticide resistant pathogens/parasites. In order to solve this problem, advanced technology, including theomictechnologies, genome analysis, LC-MS and GLC$\mathrm{ECD}$, have been introduced to provide data on the biology of honeybees and their pathogen/parasites. The resistant mechanisms of honeybees against those pathogens/parasites have started to be revealed. Management systems and antimicrobial compounds from natural products have been found to have potential in the prevention and treatment of bee diseases.

\section{Acknowledgement}

The helpful suggestions of anonymous referees and the editor are acknowledged.

\section{Funding Information}

This work was supported by Chulalongkorn University and Office of International Affairs of Chulalongkorn University.

\section{Author's Contribution}

Chanpen Chanchao: Supervised the work, sought financial support and wrote the manuscript.

Marko Stoić, Mikio Yoshiyama and Kiyoshi Kimura: Gave suggestions and drew conclusions. 


\section{Ethics}

The corresponding author confirms that all of authors have read and approved the manuscript and no ethical issues involved.

\section{References}

Alaux, C., F. Ducloz, D. Crauser and Y. Le Conte, 2010. Diet effects on honeybee immunocompetence. Biol. Lett., 6: 562-565. DOI: 10.1098/rsbl.2009.0986

Amulen, D.R., P. Spanoghe, M. Houbraken, A. Tamale and D.C. de Graaf et al., 2017. Environmental contaminants of honeybee products in Uganda detected using LC-MS/MS and GC-ECD. PLoS One, 12: e0178546-e0178546.

DOI: 10.1371 /journal.pone.0178546

Ascher, J.S. and J. Pickering, 2015. Discover life bee species guide and world checklist (Hymenoptera: Apoidea: Anthophila). http://www.discoverlife.org/mp/20q?search=Apoidea

Asensio, I., M. Vicente-Rubiano, M.J. Munoz, E. Fernandez-Carrion and J.M. Sanchez-Vizcaino et al., 2016. Importance of ecological factors and colony handling for optimizing status of apiaries in Mediterranean ecosystems. PLoS One, 11: e0164205-e0164205. DOI: 10.1371/journal.pone.0164205

Berry, J.A., W.M. Hood, S. Pietravalle and K.S. Delaplane, 2013. Field-level sublethal effects of approved bee hive chemicals on honey bees (Apis mellifera L.). PLoS One, 8: e76536-e76536. DOI: 10.1371/journal.pone.0076536

Bigio, G., H. Al Toufailia and F.L. Ratnieks, 2014. Honey bee hygienic behaviour does not incur a cost via removal of healthy brood. J. Evol. Biol., 27: 226-230. DOI: $10.1111 /$ jeb. 12288

Boligon, A.A., T.F. Brum, M. Zadra, M. Piana and C.F. Alves et al., 2013. Antimicrobial activity of Scutia buxifolia against the honeybee pathogen Paenibacillus larvae. J. Invertebr. Pathol., 112: 105-107. DOI: 10.1016/j.jip.2012.11.009

Boonsai, P., P. Phuwapraisirisan and C. Chanchao, 2014. Antibacterial activity of a cardanol from Thai Apis mellifera propolis. Int. J. Med. Sci., 11: 327-336. DOI: $10.7150 /$ ijms. 7373

Calderone, N.W., S. Lin and L.P.S. Kuenen, 2002. Differential infestation of honey bee, Apis mellifera, worker and queen brood by the parasitic mite Varroa destructor. Apidologie, 33:389-398. DOI: 10.1051/apido:2002024

Cecotti, R., E. Carpana, P. Bergomi and A. Tava, 2013. Volatile constituents of Trifolium pratense spp. nivale quantified at different growth stages and evaluation of their antimicrobial activity. Nat. Prod. Commun., 8: 1625-1628. PMID: 24427957
Cecotti, R., E. Carpana, L. Falchero, R. Paoletti and A. Tava, 2012. Determination of the volatile fraction of Polygonum bistorta L. at different growing stages and evaluation of its antimicrobial activity against two major honeybee (Apis mellifera) pathogens. Chem. Biodivers., 9: 359-369. DOI: $10.1002 / \mathrm{cbdv} .201100326$

Chemurot, M., A.M. Akol, C. Masembe, L. de Smet and T. Descamps et al., 2016. Factors influencing the prevalence and infestation levels of Varroa destructor in honeybee colonies in two highland agro-ecological zones of Uganda. Exp. Applied Acarol., 68: 497-508. DOI: $10.1007 / \mathrm{s} 10493-016-0013-x$

Clermont, A., M. Eickermann, F. Kraus, C. Georges and L. Hoffmann et al., 2014. A survey on some factors potentially affecting losses of managed honey bee colonies in Luxembourg over the winters 2010/2011 and 2011/2012. J. Apic. Res., 53: 43-56.

DOI: 10.3896/IBRA.1.53.1.04

Clermont, A., M. Eickermann, F. Kraus, L. Hoffmann and M. Beyer, 2015. Correlations between land covers and honey bee colony losses in a country with industrialized and rural regions. Sci. Total Environ., 532: 1-13. DOI: $10.1016 /$ j.scitotenv.2015.05.128

Cornman, R.S., D. Lopez and J.D. Evans, 2013. Transcriptional response of honey bee larvae infected with the bacterial pathogen, Paenibacillus larvae. PLoS One, 8: e65424-e65424. DOI: 10.1371/journal.pone.0065424

Crane, E., 2000. Prevention and treatment of diseases and pests of honeybees: The world picture. New Zealand Beekeeper, 10: 5-8.

Damiani, N., N.J. Fernandez, M.P. Porrini, L.B. Gende and E. Álvarez et al., 2014. Laurel leaf extracts for honeybee pest and disease management: Antimicrobial, microsporicidal and acaricidal activity. Parasitol. Res., 113: 701-709. DOI: $10.1007 / \mathrm{s} 00436-013-3698-3$

Damiani, N., L.B. Gende, P. Bailac, J.A. Marcangeli and M.J. Eguaras, 2009. Acaricidal and insecticidal activity of essential oils on Varroa destructor (Acari: Varroidae) and Apis mellifera (Hymenoptera: Apidae). Parasitol. Res., 106: 145-152. DOI: $10.1007 / \mathrm{s} 00436-009-1639-y$

Damiani, N., L.B. Gende, M.D. Maggi, S. Palacios and J.A. Marcangeli et al., 2011. Repellent and acaricidal effects of botanical extracts on Varroa destructor. Parasitol. Res., 108: 79-86. DOI: $10.1007 / \mathrm{s} 00436-010-2043-3$

Dance, C., C. Botias and D. Goulson, 2017. The combined effects of a monotonous diet and exposure to thiamethoxam on the performance of bumblebee micro-colonies. Ecotoxicol. Environ. Saf., 139: 194-201.

DOI: $10.1016 /$ j.ecoenv.2017.01.041 
Daughenbaugh, K.F., M. Martin, L.M. Brutscher, I. Cavigli and E. Garcia et al., 2015. Honey bee infecting Lake Sinai Viruses. Viruses, 7: 3285-3309. DOI: $10.3390 / \mathrm{v} 7062772$

Davies, J. and D. Davies, 2010. Origins and evolution of antibiotic resistance. Microbiol. Mol. Biol. Rev., 74: 417-433. DOI: 10.1128/MMBR.00016-10

DeGrandi-Hoffman, G., F. Ahumada and H. Graham, 2017. Are dispersal mechanisms changing the hostparasite relationship and increasing the virulence of Varroa destructor (Mesostigmata: Varroidae) in managed honeybee (Hymenoptera: Apidae) colonies? Environ. Entomol., 46: 737-746. DOI: 10.1093/ee/nvx077

De Miranda, J.R., R.S. Cornman, J.D. Evans, E. Semberg and N. Haddad et al., 2015. Genome characterization, prevalence and distribution of a macula-like virus from Apis mellifera and Varroa destructor. Viruses, 7: 3586-3602. DOI: $10.3390 / \mathrm{v} 7072789$

Delfinado-Baker, M., 1988. Variability and biotypes of Varroa jacobsoni Oudemans. Am. Bee. J., 128: 567-568.

Drescher, N., A.M. Klein, P. Neumann, O. Yanez and S.D. Leonhardt, 2017. Inside honey bee hives: Impact of natural propolis on the ectoparasitic mite Varroa destructor and viruses. Insects, 8: 15-15. DOI: 10.3390/insects8010015

El Zalabani, S.M., H.I. El-Askary, O.M. Mousy, M.Y. Issa and A.A. Zaitoun et al., 2012. Acaricidal activity of Swietenia mahogani and Swietenia macrophylla ethanolic extracts against Varroa destructor in honey bee colonies. Exp. Parasitol., 130:166-170. DOI: 10.1016/j.exppara.2011.10.013

Elsik, C.G., A. Tayal, C.M. Diesh, D.R. Unni and M.L. Emery et al., 2016. Hymenoptera genome database: Integrating genome annotations in HymenopteraMine. Nucleic Acids Res., 44: D793-800.

DOI: $10.1093 /$ nar/gkv1208

Evans, J.D., K. Aronstein, Y.P. Chen, C. Hetru and J.L. Imler et al., 2006. Immune pathways and defence mechanisms in honey bees Apis mellifera. Insect Mol. Biol., 15: 645-656. DOI: $10.1111 / \mathrm{j} .1365-2583.2006 .00682 . \mathrm{x}$

Fang, Y., M. Feng and and J.K. Li, 2010. Royal jelly proteome comparison between $A$. mellifera ligustica and A. cerana cerana. J. Proteome Res., 9: 2207-2215. DOI: $10.1021 /$ pr900979h

Fatrcova-Sramkova, K., J. Nozkova, M. Mariassyova and M. Kacaniova, 2016. Biologically active antimicrobial and antioxidant substances in the Helianthus annuus L. bee pollen. J. Environ. Sci. Health B, 51: 176-181.

DOI: $10.1080 / 03601234.2015 .1108811$
Fessi, H., J.P. Puisieux, N. Devissaguet, N. Ammoury and S. Benita, 1989. Nanocapsule formation by interfacial polymer deposition following solvent displacement. Int. J. Pharm., 55: R1-R4. DOI: 10.1016/0378-5173(89)90281-0

Gacic, M., N. Bilandzic, D.I. Sipusic, M. Petrovic and B. Kos et al., 2015. Degradation of oxytetracycline, streptomycin, sulphathiazole and chloramphenicol residues indifferent types of honey. Food Technol. Biotechnol., 53: 154-162.

DOI: $10.17113 / \mathrm{ftb} .53 .02 .15 .3934$

Gallai, N., J.M. Salles, J. Settele and B.E. Vaissiere, 2009. Economic valuation of the vulnerability of world agriculture confronted with pollinator decline. Ecol. Econ., 68: 810-821.

DOI: $10.1016 /$ j.ecolecon.2008.06.014

Gauthier, L., S. Cornman, U. Hartmann, F. Cousserans and J.D. Evans et al., 2015. The Apis mellifera filamentous virus genome. Viruses, 7: 3798-3815. DOI: $10.3390 / \mathrm{v} 7072798$

Genersch, E., 2010. American foulbrood in honeybees and its causative agent, Paenibacillus larvae. J. Invertebr. Pathol., 103: S10-S19. DOI: $10.1016 /$ j.jip.2009.06.015

Genersch, E., A. Ashiralieva and I. Fries, 2005. Strainand genotype-specific differences in virulence of Paenibacillus larvae subsp. larvae, a bacterial pathogen causing American foulbrood disease in honeybees. Applied Environ. Microbiol., 71: 75517555. DOI: 10.1128/AEM.71.11.7551-7555.2005

Genersch, E., E. Forsgren, J. Pentikainen, A. Ashiralieva and S. Rauch et al., 2006. Reclassification of Paenibacillus larvae subsp. pulvifaciens and Paenibacillus larvae subsp. larvae as Paenibacillus larvae without subspecies differentiation. Int. J. Syst. Evol. Microbiol., 56: 501-511. DOI: 10.1099/ijs.0.63928-0

Gonzalez, M.J., V.G. Beoletto, A.M. Agnese, M.C. Audisio and J.M. Marioli, 2015. Purification of substances from Achyrocline satureioides with inhibitory activity against Paenibacillus larvae, the causal agent of American foulbrood in honeybees' larvae. Applied Biochem. Biottechnol., 175: 3349-3359.

DOI: $10.1007 / \mathrm{s} 12010-015-1506-5$

Gonzalez-Gomez, R., G. Otero-Colina, J.A. VillanuevaJimenez, C.B. Pena-Valdivia and J.A. SantizoRincon, 2012. Repellency of the oil extract of neem seeds (Azadirachta indica) against Varroa destructor (Acari: Varroidae). Exp. Applied Acarol., 56: 261-270. DOI: 10.1007/s10493-012-9517-1

Gordon, R., N. Bresolin-Schott and I.J. East, 2014. Nomadic beekeeper movements create the potential for widespread disease in the honeybee industry. Aust. Vet. J., 92: 283-290. DOI: 10.1111/avj.12198 
Graystock, P., E.J. Blane, Q.S. McFrederick, D. Goulson and W.O.H. Hughes, 2016. Domanaged bees drive parasite spread and emergence in wild bees? IJP: PAW., 5: 64-75. DOI: 10.1016/j.ijppaw.2015.10.001

Hirai, Y., T. Suzuki, N. Inaba, N. Minoguchi and D. Takamatsu, 2016. Existence of Paenibacillus larvae genotypes ERIC I-ST2, ERIC I-ST15 and ERIC IIST10 in the western region of Aichi prefecture, Japan. J. Vet. Med. Sci., 78: 1195-1199. DOI: $10.1292 /$ jvms. 16-0041

Hagler, J.R., S. Mueller, L.R. Teuber, S.A. Machtley and A. Van Deynze, 2011. Foraging range of honey bees, Apis mellifera, in alfalfa seed production fields. J. Insect Sci., 11: 1-12. DOI: 10.1673/031.011.14401

Hernandez-Lopez, J., S. Crockett, O. Kunert, W. Schuehly and R. Bauer et al., 2014. In vitro growth inhibition by Hypericum extracts and isolated pure compounds of Paenibacillus larvae, a lethal disease affecting honeybees worldwide. Chem. Biodivers., 11: 695-708. DOI: 10.1002/cbdv.201300399

Holetz, F.B., G.L. Pessini, N.R. Sanches, D.A. Cortez and C.V. Nakamura et al., 2002. Screening of some plants used in the Brazilian folk medicine for the treatment of infectious diseases. Mem. Inst. Oswaldo Cruz., 97: 1027-1031. DOI: $10.1590 / \mathrm{S} 0074-02762002000700017$

HGSC, 2014. Finding the missing honey bee genes: Lessons learned from a genome upgrade. BMC Genom., 15: 86-86. DOI: 10.1186/1471-2164-15-86

Hu, S., M. Zhao, X. Yiyuan, Q. Mao and X. Zhou et al., 2017. Nontargeted screening and determination of Sulfonamides: A dispersive micro solid-phase extraction approach to the analysis of milk and honey samples using liquid chromatography-highresolution mass spectrometry. J. Agric. Food Chem., 65: 1984-1991. DOI: 10.1021/acs.jafc.6b05773

Johnson, R.M., M. Ellis, C. Mullin and M. Frazier, 2010. Pesticides and honey bee toxicity-USA. Apidologie, 41: 312-331. DOI: 10.1051/apido/2010018

Johnson, R.M., J.D. Evans, G.E. Robinson and M.R. Berenbaum, 2009. Changes in transcript abundance relating to colony collapse disorder in honey bees (Apis mellifera). Proc. Natl. Acad. Sci. USA, 106: 14790-14795. DOI: 10.1073/pnas.0906970106

Keeling, P., 2009. Five questions about microsporidia. PLoS Pathol., 5: e1000489-e1000489. DOI: 10.1371/journal.ppat.1000489

Knudsen, J.T., L. Tollsten and G. Bergstrom, 1993. Floral scents-a checklist of volatile compounds isolated by head-space techniques. Phytochemistry, 33: 253-280. DOI: 10.1016/0031-9422(93)85502-I

Krongdang, S., J.D. Evans, J.S. Pettis and P. Chantawannakul, 2017. Multilocus sequence typing, biochemical and antibiotic resistance characterizations reveal diversity of North American strains of the honey bee pathogen Paenibacillus larvae. PLoS One, 12: e0176831-e0176831. DOI: 10.1371/journal.pone.0176831
Kwadha, C.A., G.O. Ong'amo, P.N. Ndegwa, S.K. Raina and A.T. Fombong, 2017. The biology and control of the greater wax moth, Galleria mellonella. Insects, 8: 61-61. DOI: 10.3390/insects8020061

Lopes, L.Q.S., C.G. Santos, R.D.A. Vaucher, L. Gende and R.P. Raffin et al., 2016. Evaluation of antimicrobial activity of glycerol monolaurate nanocapsules against American foulbrood disease agent and toxicity on bees. Microb. Pathog., 97: 183-188. DOI: 10.1016/j.micpath.2016.05.014

Marshall, B.M., D.J. Ochieng and S.B. Levy, 2009. Commensals: Underappreciated reservoirs of resistance. Microbe, 4: 231-238.

Mill, A.C., S.P. Rushton, M.D. Shirley, G.C. Smith and P. Mason et al., 2014. Clustering, persistence and control of a pollinator brood disease: Epidemiology of American foulbrood. Environ. Microbio., 1 16: 3753-3763. DOI: 10.1111/1462-2920.12292

Mourad, A.K., O.A. Zaghloul, M.B. El Kady, F.M. Nemat and M.E. Morsy, 2005. A novel approach for the management of the chalkbrood disease infesting honeybee Apis mellifera L. (Hymenoptera: Apidae) colonies in Egypt. Commun. Agric. Applied Biol. Sci., 70: 601-611. PMID: 16628894

Muller, M. and S. Kersten, 2003. Nutrigenomics: Goals and strategies. Nat. Rev. Genet., 4: 315-322. DOI: $10.1038 / \mathrm{nrg} 1047$

Mullin, C.A., M. Frazier, J.L. Frazier, S. Ashcraft and R. Simonds, 2010. High levels of miticides and agrochemicals in North American apiaries: Implications for honey bee health. PLoS One, 5: e9754-e9754. DOI: 10.1371/journal.pone.0009754

Multinelli, F., 2011. The spread of pathogens through trade in honey bees and their products (including queen bees and semen): Overview and recent developments. Sci. Tech. Rev. Office Int. Epizooties (Paris), 30: 257-271. PMID: 21809768

Nagamuthu, N., 2016. Statistical overview of the Canadian honey and bee industry 2015, Horticulture and cross sectoral division, Marker analysis and information section, Agriculture and agri-food Canada.

NAS, 2007. Status of Pollinators in North America. 1st Edn., National Academies Press, Washington, DC, ISBN-10: 0309102898, pp: 326.

Nazzi, F., R. Bortolomeazzi, G. Della Vedova, F. Del Piccolo and D. Annoscia et al., 2009. Octanoic acid confers to royal jelly varroa-repellent properties. Naturwissenschaften, 96: 309-314. DOI: $10.1007 / \mathrm{s} 00114-008-0470-0$

Nicholson, J.K. and J.C. Lindon, 2008. Systems biology: Metabonomics. Nature, 455: 1054-1056. DOI: $10.1038 / 4551054 a$

Okumura, K., R. Arai, M. Okura, T. Kirikae and D. Takamatsu et al., 2011. Complete genome sequence of Melissococcus plutonius ATCC 35311. J. Bacteriol., 193: 4029-4030. DOI: 10.1128/JB.05151-11 
Oldroyd, B.P., 1999. Coevolution while you wait: Varroa jacobsoni, a new parasite of western honeybees. Trends Ecol. Evol., 14: 312-315. DOI: $10.1016 / \mathrm{S} 0169-5347(99) 01613-4$

Oldroyd, B.P., 2007. What's killing American honey bees? PLoS Biol., 5: e168-e168. DOI: 10.1371/journal.pbio.0050168

Owen, R., 2017. Role of human action in the spread of honey bee (Hymenoptera: Apidae) pathogens. J. Econ. Entomol., 110: 797-801. DOI: 10.1093/jee/tox075

Pellegrini, M.C., R.M. Alonso-Salces, M.L. Umpierrez, C. Rossini and S.R. Fuselli, 2017. Chemical composition, antimicrobial activity and mode of action of essential oils against Paenibacillus larvae, ethiological agent of American foulbrood on Apis mellifera. Chem. Biodivers., 14: e1600382e1600382. DOI: $10.1002 / \mathrm{cbdv} .201600382$

Pernal, S.F., R.L. Albright and A.P. Melathopoulos, 2008. Evaluation of the shaking technique for the economic management of American foulbrood disease of honey bees (Hymenoptera: Apidae). J. Econ. Entomol., 101: 1095-1104. DOI: 10.1093/jee/101.4.1095

Piana, M., T.F. de Brum, A.A. Boligon, C.F. Alves and R.B. de Freitas et al., 2015. In vitro growthinhibitory effect of Brazillianplants extracts against Paenibacillus larvae and toxicity in bees. An Acad. Bras. Cienc., 87: 1041-1047. DOI: $10.1590 / 0001-3765201520140282$

Poelchau, M.F., B.S. Coates, C.P. Childers, A.A. Peréz de León and J.D. Evans et al., 2016. Agricultural applications of insect ecological genomics. Curr. Opin. Insect Sci., 13: 61-69. DOI: 10.1016/j.cois.2015.12.002

Potts, S.G., J.C. Biesmeijer, C. Kremen, P. Neumann and O. Schweiger et al., 2010. Global pollinator declines: Trends, impacts and drivers. Trends Ecol. Evol., 25: 345-353. DOI: 10.1016/j.tree.2010.01.007

Razavi, S.M., M. Asadpour, A. Jafari and S.H. Malekpour, 2015. The field efficacy of Lepidium latifolium and Zataria multiflora methanolic extracts against Varroa destructor. Parasitol. Res., 114: 4233-4238. DOI: 10.1007/s00436-015-4661-2

Rinkevich, F.D., R.G. Danka and K.B. Healy, 2017. Influence of Varroa mite (Varroa destructor) management practices on insecticide sensitivity in the honey bee (Apis mellifera). Insects, 8: 9-9. DOI: $10.3390 /$ insects8010009

Sabate, D.C., M.J. Gonzalez, M.P. Porrini, M.J. Eguaras and M.C. Audisio et al., 2012. Synergistic effect of surfactin from Bacillus subtilis $\mathrm{C} 4$ and Achyrocline satureioides extracts on the viability of Paenibacillus larvae. World J. Microbiol. Biotechnol., 28: 1415-1422.

DOI: $10.1007 / \mathrm{s} 11274-011-0941-\mathrm{x}$
Schick, R.S., J.J.D. Greenwood and S.T. Buckland, 2017. An experiment on the impact of a neonicotinoid pesticide on honeybees: The value of a formal analysis of the data. Env. Sci. Eur., 29: 4-4. DOI: $10.1186 / \mathrm{s} 12302-016-0103-8$

Schlievert, P.M., J.R. Deringer, M.H. Kim, S.J. Projan and R.P. Novick, 1992. Effect of glycerol monolaurate on bacterial growth and toxin production. Antimicrob. Agents Chemother., 36: 626-631. DOI: 10.1128/AAC.36.3.626

Schmehl, D.R., P.E. Teal, J.L. Frazier and C.M. Grozinger, 2014. Genomic analysis of the interaction between pesticide exposure and nutrition in honey bees (Apis mellifera). J. Insect Physiol., 71: 177-190. DOI: 10.1016/j.jinsphys.2014.10.002

Schmid-Hempel, P., 1998. Parasites in Social Insects. 1st Edn., Princeton, New Jersey, pp: 392.

Schmid-Hempel, P., 2005. Evolutionary ecology of insect immune defenses. Annu. Rev. Entomol., 50: 529-551.

DOI: 10.1146/annurev.ento.50.071803.130420

Schmid-Hempel, P., 2008. Parasite immune evasion: A momentous molecular war. Trends Ecol. Evol., 23: 318-326. DOI: 10.1016/j.tree.2008.02.011

Shin, Y.K. and K.Y. Kim, 2016. Macelignan inhibits bee pathogenic fungi Ascosphaera apis growth through HOG1 pathway. Braz. J. Med. Biol Res., 49: e5313e5313. DOI: 10.1590/1414-431X20165313

Solignac, M., J.M. Cornuet, D. Vautrin, Y. Le Conte and D. Anderson et al., 2005. The invasive Korea and Japan types of Varroa destructor, ectoparasitic mites of the Western honeybee (Apis mellifera), are two partly isolated clones. Proc. Biol. Sci., 272: 411-419. DOI: $10.1098 / \mathrm{rspb} .2004 .2853$

Sorci, G., 2013. Immunity, resistance and tolerance in bird-parasite interactions. Parasite Immunol., 35: 350-361. DOI: 10.1111/pim.12047

Spivak, M. and G.S. Reuter, 2001. Resistance to American foulbrood disease by honey bee colonies Apis mellifera bred for hygienic behavior. Apidologie, 32: 555-565.

DOI: 10.1051/apido:2001103

Teerasripreecha, D., P. Phuwapraisirisan, S. Puthong, K. Kimura and M. Okuyama et al., 2012. In vitro antiproliferative/cytotoxic activity on cancer cell lines of a cardanol and a cardol enriched from Thai Apis mellifera propolis. BMC Complement. Altern. Med., 12: 27. DOI: 10.1186/1472-6882-12-27

Tian, B., N.H. Fadhi, J.E. Powell, W.K. Kwong and N.A. Moran, 2012. Long-term exposure to antibiotics has caused accumulation of resistance determinants in the gutmicrobiota of honeybees. MBio., 3: e00377-e00377.

DOI: $10.1128 / \mathrm{mBio} .00377-12$ 
Traynor, K.S., K. Rennich, E. Forsgren, R. Ross and J. Pettis et al., 2016. Multiyear survey targeting disease incidencein US honey bees. Apidologie, 47: 325-347. DOI: 10.1007/s13592-016-0431-0

Umpierrez, M.L., E. Santos, Y. Mendoza, P. Altesor and C. Rossini, 2013. Essential oil from Eupatorium buniifolium leaves as potential varroacide. Parasitol. Res., 112: 3389-3400.

DOI: $10.1007 / \mathrm{s} 00436-013-3517-\mathrm{x}$

VanEngelsdorp, J., D.M. Caron, J. Hayes, R. Underwood and M. Henson et al., 2012. A national survey of managed honey bee 2010-11 winter colony losses in the USA: Results from the Bee Informed Partnership. J. Apic. Res., 51: 115-124.

DOI: 10.3896/IBRA.1.51.1.14

Vezeteu, T.V, O. Bobis, R.F.A. Moritz and A. Buttstedt, 2017. Food to some, poison to others-honeybee royal jelly and its growth inhibiting effect on European Foulbrood bacteria. Microbiologyopen, 6: e00397-e00397. DOI: 10.1002/mbo3.397

Williams, I.H., 2010. Biocontrol-Based Integrated Management of Oilseed Rape Pests. 1st Edn., Springer Netherlands, Dordrecht, ISBN-10: 904813983X, pp: 461.
Winfree, R., R. Aguilar, D.P. Vazquez, G. LeBuhn and M.A. Aizen, 2009. A meta-analysis of bees' responses to anthropogenic disturbance. Ecology, 90: 2068-2076. DOI: 10.1890/08-1245.1

Wu, J.L., C.X. Zhou, P.J. Wu, J. Xu and Y.Q. Guo et al., 2017. Brain metabolomic profiling of eastern honey bee (Apis cerana) infested with the mite Varroa destructor. PLoS One, 12: e0175573-e0175573. DOI: 10.1371 /journal.pone. 0175573

Yue, D., M. Nordholf, L.H. Wieler and E. Genersch, 2008. Fluorescence in Situ Hybridization (FISH) analysis of the interactions between honeybee larvae and Paenibacillus larvae, the causative agent of American foulbrood of honeybee (Apis mellifera). Environ. Microbiol., 10: 1612-1620. DOI: $10.1111 / \mathrm{j} .1462-2920.2008 .01579 . \mathrm{x}$

Zhang, Y., G. Zhang, X. Huang and R. Han, 2014. Proteomic analysis of Apis cerana and A. mellifera larvae fed with heterospecific royal jelly and by CSBV challenge. PLoS One, 9: e102663-e102663. DOI: 10.1371/journal.pone.0102663

Zhukovskaya, M., A. Yanagawa and B.T. Forschler, 2013. Grooming behavior as a mechanism of insect disease defense. Insects, 4: 609-630. DOI: $10.3390 /$ insects4040609 